\section{ROGER DYSON}

When the present government took office in 1979 it faced some alarming predictions about manpower and pay in the public services. On the basis of trends over two decades it was predicted that National Health Service manpower would rise from just over $5 \%$ of the working population to something over $8 \%$ and that employment in the Civil Service, the Health Service, and local government taken together would come to constitute roughly a fifth of the total working population. Furthermore, because of the interrelationships between these services in the determination of pay it was clear that the government had insufficient control over this sector of the economy. Pay in the Civil Service was determined by an independent pay research unit and the results of that were applied directly to NHS pay for those white collar staff not in the medical and nursing professions. Local government pay also could not be directly controlled by the government because of the freedom of local authorities to raise their own income, and local government manual workers' pay strictly determined the pay of ancillary staff in the NHS. Finally, the $50 \%$ of NHS staff in the nursing and paramedical professions not directly concerned in this pay procedure were, none the less, periodically pulled into line with these other NHS groups by ad hoc committees of inquiry. The fact that this semiautomatic system was outside direct government control, coupled with the enormous significance for the rest of the economy of this block of pay settlements within the public services, suggested that, if the existing trends continued to the end of the century, the government would not have sufficient control of public sector pay and thus of public expenditure.

The Conservative government's response to the rising manpower figures has been dramatic. It has attempted to "beat the trend lines on the head" in each of the three services separately. Cuts in the Civil Service have been direct and dramatic, while local government has been controlled by penalty clauses in the rate support grant aimed principally at manpower though under the general heading of limiting the rise in expenditure. In the NHS a combination of efficiency savings, privatisation, and the recently appointed manpower inquiry have all been attempts to influence the numbers employed, despite the rising demand for health care services.

\section{Breaking the links}

The crucial task for the government, however, if it wished to avoid the end of century predictions, was to re-establish more direct government control over the level of pay settlements in these three services. Over the past three years the policy chosen has been to break the links between the services and at the same time to break the automatic right to comparability that worked through the pay research system. So far the government has had a quite startling success and it has largely achieved its objective in a series of stages.

Department of Adult Education, University of Keele, Stafis

ROGER DYSON, BA, PHD, director and professor. Chairman, North Staffordshire Health Authority
In 1979-80 the government introduced the cash limits policy. for public service funding. This allowed the civil servants to be paid more than their Health Service equivalents on the ground\$ that the Civil Service was increasing in efficiency because of the government's manpower cuts, whereas the NHS was still in: creasing its manpower. This allowed the government to secure a temporary break in pay relations of 30 years' standing between $\vec{\omega}$ the Civil Service and the NHS that was extended for a second year in the April 1981 pay settlement. Exactly the same reasoning but without the argument of increased efficiency, allowed the government to break the links between local government ando Health Service manual workers by April 1981. By that date the government had achieved the first stage of its policy by breaking the automatic pay movements between the three services, albeif on a "temporary" basis.

The second step was to dismantle the Civil Service pay research machinery in order to break the fixed and automatic comparability that it ensured between the private sector and the Civil Service. This was achieved despite the Civil Service strike of 1981 on the understanding that the government would estab lish an inquiry to re-examine the way in which pay research? was used in the Civil Service.

\section{Brilliant conceptual stroke}

By the start of 1982 the government had achieved considerable success but its arrangements were only temporary. The Civio Service was still expecting a totally comparability based system and the NHS was still thinking in terms of the re-establishmen of links with the Civil Service and local government. The nex? and hardest stage for the government was to find some way of formally institutionalising the split between the three services. while not conceding the automatic right to comparabilit in any. This seemingly impossible task was achieved by brilliant conceptual stroke that was contained in the report oo the Megaw committee of inquiry into Civil Service pay, pub? lished in July 1982. ${ }^{1}$

Objective research was still to be used to establish com parability with the private sector, but instead of this informatiog being aggregated to produce specific figures for pay increases in different occupations, the spread of settlements in the private sector was to be used to establish an interquartile range withis which the government and the Civil Service unions would nego $\overline{\bar{N}}$ tiate. The importance of this was that it would leave the govern ment free to screw the settlement down below the median in those years when the government's economic policy dictate $\bar{P}$ greater caution in public service pay settlements, while not at the same time "breaking" pay systems or pay agreements.

Having found a device to free itself from the automatic acceptance of comparability results, the government's final tas is now to institutionalise the separation of the NHS from botio the Civil Service and local government. This task is now unde? way.

In this task the government has been greatly helped by the Trades Union Congress, which produced a report in Septembeg 1981 Improving Industrial Relations in the NHS. ${ }^{2}$ This played into the government's hands. The report suggested an indepen dent data bank for the NHS, the results of which would the 
lead to collective bargaining about the final level of NHS pay with no direct link either to the Civil Service or to local government. A separate pay information system for the NHS with collective bargaining using the Megaw principles-that is, freedom to settle within the interquartile range-is just what the government is seeking to achieve. The TUC is not committed at all to the Megaw principles, but the government has already urged members of the TUC Health Services Committee to consider this package.

At the end of the recent pay dispute there was a two year arrangement which gives the government, management, and the staff side until April 1984 to establish a reformed system of pay bargaining for the NHS. If the government and the TUC do agree to an independent data bank with free collective bargaining within the interquartile range the government will have achieved its final major objective of institutionalising the break between the three public services. Once achieved this system would allow the government to negotiate levels of pay in the smaller and more sensitive Civil Service that, when necessary, would exceed levels of pay in the larger and more economically important NHS. This would diminish the threat of difficult industrial action in the Civil Service at the expense of increasing such action in the NHS. Such an outcome would have several important advantages for the government because the Civil Service and local government are far less attractive than the NHS as the future cockpit within which the government's view of sensible pay settlements can be fought out.

\section{Effect of internal relativities in NHS}

The decision to establish a pay review body for nurses, midwives, and professions supplementary to medicine means that, together with the medical and dental professions, a half of NHS staff would have their pay determined by an independent review body. At first glance this would seem to imply that pay would be free of government control. The important point to remember, however, is that the current evidence of the TUC, of the National Assocation of Health Authorities, ${ }^{3}$ and of many academic commentators is that the new review bodies should be asked to give greatest attention to the maintenance of internal NHS pay relativities. Assuming that the government writes this firmly into the review bodies' job descriptions, the dominant influence on the pay of nurses and the professions supplementary to medicine will be the pay settlements in the other half of the NHS, which themselves will have been the result of bargaining within the interquartile range.

The other great advantage of the new pay review bodies in helping to achieve the government's objective is the assumption that their staff will accept the results of such reviews in exchange for a commitment not to use industrial action. This has the attraction that any conflict over pay in the NHS, because of the failure to achieve an offer sufficiently high within the interquartile range, would face the trade unions with considerable difficulties. If medical, nursing, and paramedical professions continue to work together with senior management it offers the prospect of long drawn out but ultimately unsuccessful strikes by manual workers and the more junior white collar workers. Under these conditions the government could not have picked a better service to show, whenever necessary, its determination to hold public service pay settlements.

As an interested observer of public sector pay determination over the past few years, I can only admire both the success and conceptual brilliance of government policy. Somewhere in the Treasury I am convinced that there is someone who deserves more than the usual "gong." As a district health authority chairman, however, I can only lament most bitterly the implication of a change that swings the NHS into centre stage in the future determination of public pay policy. Until 1980 the NHS was relatively free from major pay disputes because of a tacit understanding that the NHS could wait and pick up the results of external pay settlements. From 1984 onwards the NHS pay

\section{Vice presidents}
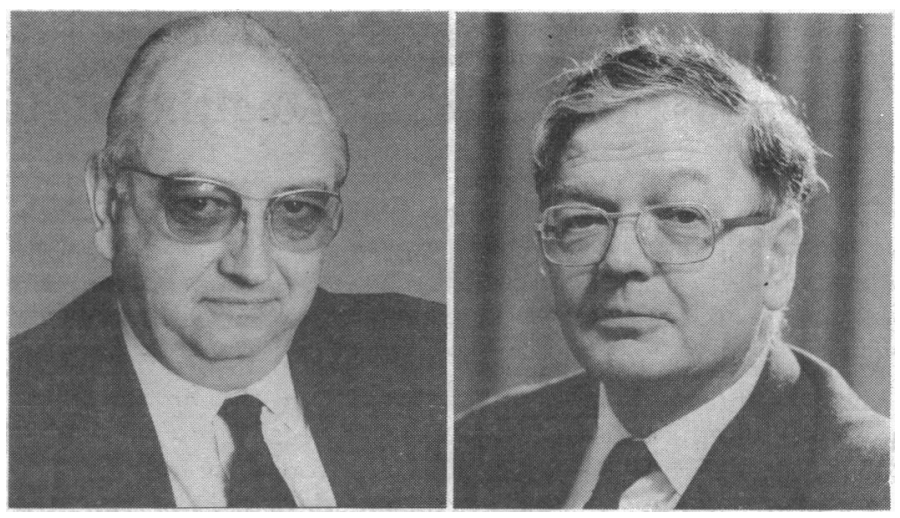

The election of two new vice presidents has been recommended to the 1983 annual representative body-Dr W Keith Davidson, chairman of the Scottish council 1978-81 and one of the negotiators of the General Medical Services Committee between 1972 and 1981 (left); and Mr David Bolt, chairman of the Central Committee for Hospital Medical Services since 1979.

settlement is going to become one of the politically most sensitive settlements in the economy. It probably will not mean pay conflict every single year, but the prospect of regular pay confrontations is almost certain and the implications of this for patient care are serious indeed.

\section{Institutionalising pay determination for 30 years?}

Within the next two months or so the management side of the NHS will have to tell the Secretary of State its own views of future pay determination, and many eminent academics, ex-chairmen of authorities, and senior NHS officers now seem to be backing the system described above as the government's own option. My personal reaction is to think that they are putting their heads, or more precisely the head of the NHS into a noose, which once it is tightened will institutionalise NHS pay determination for the next 30 years. Only the National Association of Health Authorities has so far come out openly in favour of a pay policy that seeks to keep the NHS in its off stage position in the fight over pay determination by recommending that the NHS should be allowed to pick up automatically whatever are the results of bargaining in the Civil Service within the interquartile range. This still offers the government the opportunity to control the final level of settlements in each service but it switches the principal emphasis in bargaining back to the Civil Service. If the proposals of the National Association of Health Authorities did enjoy full management side support the odds are still against it because of the strong dislike of all governments of using their own employees, the civil servants, as a means of trying to establish their pay policies. One thing is certain, however: the events of the next few months will be more important in determining the industrial relations and pay prospects of the NHS than at any time since the establishment of the Whitley Council system.

\section{References}

1 Chancellor of the Exchequer. Inquiry into civil service pay. Cmnd 8590 London: HMSO, 1982. (Megaw report.)

2 Trades Union Congress. Improving industrial relations in the NHS. London: TUC, 1981.

3 The National Association of Health Authorities in England and Wales. The future of pay determination in the NHS. Birmingham: NAHA, 1982

(Accepted 7 March 1983) 